\title{
SAMPLING PLAN FOR ASSESSING BROWN ROT SEVERITY IN PEACHES SUBJECTED TO DIFFERENT PLANT EXTRACTS ${ }^{1}$
}

\author{
KELLY PAZOLINI ${ }^{2 *}$, IDALMIR DOS SANTOS ${ }^{3}$, IDEMIR CITADIN $^{3}$, LINDOLFO STORCK $^{3}$, MARIANA FABER $^{4}$ \\ FLORES $^{4}$
}

\begin{abstract}
The identification of brown rot control derivatives has been the focus of intense research owing to the negative effects of the unrelenting usage of fungicides. Brown rot, caused by Monilinia fructicola, is an important post-harvest disease of peaches. The goal of this study was to estimate the optimum sample size of peaches in order to assess the average lesion size and the influence of different plant extracts on the fruits. Three preparation forms (FPE) were evaluated, as well as another seven forms of application (FAE) of canola and mustard extracts on peaches, with applications of the pathogen's inoculum. Five fruits were utilized in five repetitions per treatment. Evaluation involved measurement of the fruits' lesioned areas. The necessary sampling size was determined for estimation of the averages for each treatment and experiment. For measurement of the lesion size, 99 fruits in FPE and 23 fruits in FAE were sufficient for estimating the average with an estimation error of $10 \%$. Based on the same estimation error, the sampling size is contingent on the extracts (canola, and mustard), batches of fruits, forms of extraction, and extract application on the fruits.
\end{abstract}

Keywords: Monilinia fructicola. Experimental Precision. Sample Size. Post-harvest.

\section{PLANO AMOSTRAL PARA A AVALIAÇÃO DA SEVERIDADE DE PODRIDÃO-PARDA EM PÊSSEGOS SUBMETIDOS A DIFERENTES EXTRATOS VEGETAIS}

RESUMO - Devido aos efeitos da utilização indiscriminada de fungicidas, diversos estudos vêm sendo desenvolvidos na busca por formas alternativas de controle da podridão-parda, causada por Monilinia fructicola, em pós-colheita de pêssego. O objetivo deste estudo foi estimar o tamanho ótimo de amostra para avaliar a média do tamanho da lesão pêssegos e a influência de diferentes extratos vegetais nos frutos sobre o tamanho de amostra. Foi conduzido um experimento de três formas de preparo (FPE) e outro experimento de sete formas de aplicação (FAE) de extratos de canola e mostarda sobre pêssegos, com posterior aplicação do inóculo do patógeno. Foram usados cinco frutos em cinco repetições por tratamento. As avaliações foram feitas através da medição da área da lesão nos frutos. Foi determinado o tamanho de amostra necessário para a estimacão da média para cada tratamento e cada experimento. Para a mensuração do tamanho da lesão, 99 frutos em FPE e 23 frutos em FAE são suficientes para a estimação da média com um erro de estimação de $10 \%$ da média. Usando um mesmo erro de estimação, o tamanho de amostra (número de frutos) depende dos extratos (canola e mostarda), lotes de frutos e formas de extração e de aplicação dos extratos nos frutos.

Palavras-chave: Monilinia fructicola. Precisão experimental. Tamanho de amostra. Pós-colheita.

\footnotetext{
*Corresponding Author

${ }^{1}$ Received for publication in $04 / 01 / 2014$; accepted in $02 / 16 / 2016$.

Paper extracted from the master dissertation of the first author.

${ }^{2}$ Department of Plant Pathology and Nematology, Escola Superior de Agricultura "Luiz de Queiroz", Piracicaba, SP, Brazil; kellypazolini@usp.br.

${ }^{3}$ Agronomy postgraduate program, Universidade Tecnológica Federal do Paraná, Pato Branco, PR, Brazil; idalmir@utfpr.edu.br, idemir.citadin@gmail.com, lindolfostorck@gmail.com.

${ }^{4}$ Sector of Agricultural Science, Universidade Federal do Paraná, Curitiba, PR, Brazil; marifaberflores@gmail.com.
} 


\section{INTRODUCTION}

Brazil is the thirteenth largest producer of peaches and nectarines (Prunus persica L. Batsch) worldwide, with a yield of approximately 220,000 tons of fruit in 2011 (FAO, 2012). Although the average productivity has risen from $5,833 \mathrm{~kg} \mathrm{ha}^{-1}$ in 1999 to $11,355 \mathrm{~kg} \mathrm{ha}^{-1}$ in 2009 , domestic production is not sufficient to meet the country's supplies (FACHINELLO et al., 2011). Loss of product caused by diseases is one of the reasons for lower domestic peach productivity. Brown rot (Monilinia fructicola (Wint.) Honey) occurs during pre- and post-harvests on peaches, and is one of the main diseases in this culture (ZHOU et al., 2008; SISQUELLA et al., 2013a).

In order to improve the quality of the fruits and reduce the relentless use of fungicides, various studies have investigated alternatives to brown rot control during post-harvest. In these studies, peaches are subjected to different treatments and, after a period of incubation, the lesioned area established by the fungus $M$. fructicola is evaluated. However, varying numbers of repetitions and fruits per repetition are employed in these studies, ranging from 3 to 5 repetitions and 5 to 25 fruits per repetition (KARABULUT et al., 2002; MARI et al., 2008; ZHOU et al., 2008; THOMIDIS and EXADAKTYLOU, 2010; CASALS et al., 2010; LIU et al., 2012; YANG et al., 2012; CHEN et al., 2013; JANISIEWICZ et al., 2013; SISQUELLA et al, 2013a; SISQUELLA et al., 2013b).

In assessing the extent of damage to the peaches subjected to various treatments, it is important to obtain a properly dimensioned and accurate sample size, to account for the time requirement and financial and human resources available. The sample size is proportional to the variability of the data and to the desired reliability of the median estimate, which is inversely proportional to the estimation error specified a priori by the researcher. An optimum sample size improves research efficiency, allowing for accurate acquisition of estimates (BARBETTA et al., 2004).

Determination of sample size has been performed to assess the morphologic, phenotypic, and productive features of corn (FERNANDES; SILVA, 1996; SILVA et al., 1998; STORCK et al., 2007), popping corn (CATAPATTI et al., 2008), sugarcane (LEITE et al., 2009), soybean (CARGNELUTTI FILHO et al., 2009), crambe (CARGNELUTTI FILHO et al., 2010b), castor-oilplant CARGNELUTTI FILHO et al., 2010a), and haricot beans (HAESBAERT et al., 2011).

The sample sizes were determined in order to quantify disease lesions, such as citrus canker (BELASQUE JÚNIOR et al., 2008), and pests, such as Dichopelmus notus (LÚCIO et al., 2009). For peaches subjected to different forms of storage, the sample size was determined to assess flesh firmness, epidermis background color (TOEBE et al., 2011), pulp firmness, mass, acidity, and juiciness (TOEBE et al., 2012). However, knowledge of the number of fruits per batch and treatment for evaluation of the lesioned area due to brown rot on peaches is currently unknown.

Therefore, the goal of this study was to estimate the optimum size of samples in order to evaluate the severity of brown rot compared to the average size of the lesioned area on peaches, as well as to evaluate the influence of different plant extracts on sample size.

\section{MATERIAL AND METHODS}

Peaches were obtained from commercial orchards in Pato Branco-Parana. They were selected based on size, uniformity, maturation, and absence of damages. Prior to the application of treatments, all peaches were disinfected through immersion in sodium hypochlorite at $0.5 \%$.

\section{Pathogen inoculum}

The M. fructicola fungus was isolated from infected fruits and maintained in potato- dextroseagar (PDA) culture medium at $24^{\circ} \mathrm{C}$. Conidia suspension was obtained by washing a pure culture of M. fructicola after 10 days of growth. The suspension concentration was adjusted using a hemacytometer at $10^{4}$ conidia $\mathrm{mL}^{-1}$.

\section{Preparation of the plant extracts}

Canola and Indian mustard (hybrids Ayola 4333 and Q 6501, accordingly) were collected at full bloom, dried out at $50^{\circ} \mathrm{C}$ for 72 hours, and grounded using a $0.25 \mathrm{~mm}$ grinder. The subsequent powder was stored in a plastic container at $4^{\circ} \mathrm{C}$.

The aqueous extracts of canola and Indian mustard were produced at a concentration of $12 \%$ through different extraction methods: simple extraction, infusion, and maceration. For simple extraction, the powder of the respective plant was mixed with distilled water at room temperature and then filtered. For maceration extraction, a similar procedure was performed, except that the extract was filtered only after 8 hours of resting in the dark. For infusion extraction, water at $100^{\circ} \mathrm{C}$ was added and after 20 minutes in the dark, the mixture was filtered. Extracts were used immediately after preparation.

\section{Experiment - form of preparation of the extract (FPE)}

Previously selected and disinfected fruits were immersed in different plant extracts for 30 seconds. Afterwards, they were subjected to two mechanical lesions in the equatorial portion on 
opposite sides and then sprayed with $1 \mathrm{~mL}$ of a $M$. fructicola conidia suspension $\left(10^{4}\right.$ conidia $\left.\mathrm{mL}^{-1}\right)$. In separate experiments for canola and mustard, the treatments employed were forms of extract preparation (maceration, infusion, and simple extraction). Distilled water served as the control. After application of the treatments, the fruits were stored at $24^{\circ} \mathrm{C}$ for three days. The severity of the disease was evaluated by measurement of the lesioned area $\left(\mathrm{cm}^{2}\right.$ fruit $\left.{ }^{-1}\right)$, which was calculated as the average of the two lesions in the equatorial portion on opposite sides of each fruit.

A total of 25 fruits were used, divided into five repetitions of five fruits. The experiments were repeated in two batches (batch 1 and batch 2). Batch I was performed with fresh harvested fruits and batch 2 was performed with fruits that had been previously stored at $5^{\circ} \mathrm{C}$ for 4 days.

\section{Experiment - forms of application of the extracts (FAE)}

Previously selected and disinfected fruits were subjected to the following treatments: 1) control; 2) inoculation and application of the extract; 3) application of the extract and inoculation; 4) application of the extract, inoculation, thermotherapy followed by further application of the extract; 5) application of the extract, inoculation and thermotherapy; 6) inoculation and thermotherapy, and 7) inoculation, thermotherapy, and extract application. For each treatment, 25 fruits were utilized, divided into five repetitions of five fruits. The experiments were repeated twice (batch 1 and batch 2).

For thermotherapy, the fruits were immersed in distilled water at $50^{\circ} \mathrm{C}$ for $30 \mathrm{~s}, 30 \mathrm{~min}$ after inoculation. The inoculation, application of the vegetable extracts, storage of the fruits, the experimental design, and evaluation were performed as previously described.

\section{Statistical Analysis}

For the feature measured on the five fruits (lesion size, $\mathrm{cm}^{2}$ fruit ${ }^{-1}$ ) obtained from each one of the five repetitions of each experiment, a variance analysis was performed, according to the entirely random design with five repetitions and five samples per experimental unit. Hypotheses related to the treatment effect and experimental errors (variance among repetitions) were tested according to Barbin (1998). Selective accuracy statistics (SA), an experimental precision measurement, was estimated as follows:

$\mathrm{SA}=(1-1 / \mathrm{Fc})^{1 / 2}$, for $\mathrm{Fc} \geq 1 ;$ and $\mathrm{SA}=0$, for $\mathrm{Fc}<1$, where $\mathrm{Fc}$ is the value of $\mathrm{F}$ test for treatment.

For each experiment (FPE and FAE), extracts (canola and mustard), batches of fruits (batch 1 and batch 2), and the 25 fruits (five repetitions of five fruits) were considered as the sample for each of the treatments applied. Considering the values measured on the 25 fruits, descriptive statistics (minimum and maximum values, median, standard deviation, and variance coefficient) were determined. To verify the possibility of using Student's $t$-distribution in estimating the optimum sampling size, we tested hypotheses related to asymmetry (Ho: asymmetry $=0$, by t-test with $\mathrm{p}=0.05$ ), with kurtosis (Ho: kurtosis $=$ 3 , by t-test with $\mathrm{p}=0.05$ ), and adherence to the normal (Gaussian) distribution by Lilliefors test ( $\mathrm{p}=$ 0.05) (BARBETTA et al., 2004). The computing application software SAEG (2007) was utilized for these tests.

Sample size $(\eta)$ was calculated for semiamplitudes of the confidence interval (SACI), equal to $2,4,6,8$ and $10 \%$ of the average estimate $(\mathrm{m})$, with a confidence level (1- $\alpha)$ of $95 \%$, by means of

$$
\eta=\frac{t_{\alpha / 2}^{2} s^{2}}{(\mathrm{SACI})^{2}}
$$

the expression

(BARBETTA et al., 2004), where $t_{\alpha / 2}$ is the critical value of the $t$-Student distribution. Accordingly, $\mathrm{P}\left(\mathrm{t}>\mathrm{t}_{\alpha / 2}\right)=\alpha / 2$, with (n1) degrees of freedom, $\alpha=5 \%$ of error probability, and $s^{2}$ is the variance estimation. Afterwards, $\eta$ was fixed as the total of fruits $(n=25)$ utilized per treatment for calculation of the semi-amplitude of the confidence interval (SACI), in percentage of the average estimation $(\mathrm{m})$ for each treatment, extract, and batch using the expression

$$
\mathrm{SACI}=100 \frac{\mathrm{t}_{\alpha / 2} \mathrm{~s}}{\mathrm{~m} \sqrt{\eta}}
$$

(BARBETTA et al., 2004), where $\mathrm{s}$ is the estimation of the sampling standard deviation. Calculations were conducted using the Excel software.

\section{RESULTS AND DISCUSSION}

The results of the variance analysis for analysis of different forms of extract preparations (FPE) and extract applications (FAE) using the two fruit batches and extracts (canola and mustard) are presented in Table 1. For FPE analysis, the variance among repetitions is null for both extracts and batches. In cases where the variance among repetitions is null, the experimental units are considered homogeneous, and the variance existing among repetitions is due only to the sampling variance (variance within the repetition). The precision of the comparison of the averages of each treatment depends on the magnitude of the variance estimate of the median of a treatment. Therefore, a 
lower variance estimate indicates good precision. In this model, with entirely casual design with samplings in repetitions, the variance estimate is equal to $\mathrm{MS}_{\mathrm{VA}} / \mathrm{JK}(\mathrm{J}=$ repetitions; $\mathrm{K}=$ number of fruits per repetition). As a result, in the case of the FPE experiment, the number of repetitions (J) leads to reduced relative relevance (BARBIN, 1998) in resizing the combinations of $\mathrm{JK}$ fruits per treatment, where the total number $(\mathrm{n}=\mathrm{JK}=25$ fruits) in the experiment is maintained. Therefore, in an experiment in which the variance among repetitions is not meaningful, it would be more efficient to employ a larger sample size (JK) per repetition so that $\mathrm{JK}$ is maintained for all treatments. Considering that 25 fruits were used per treatment, one alternative to using five fruits for the FPE experiment is to use a smaller number of repetitions and a larger sample size. For example, it would be useful to do two repetitions of 13 fruits. In the FAE experiment where the variance among repetitions was statistically meaningful $(\mathrm{p}<0.05)$, the strategy would be the opposite, which is to employ the maximum number of repetitions and the minimum number of samples per repetition (e.g. 13 repetitions of two fruits).

Table 1. Variance analysis with degrees of freedom (DF) and mean square (MS) of the sources of variance (SV), forms of preparation (FPE), and canola extract application (FAE) in two batches (C1 and C2) as well as mustard in two batches (M1, and M2), variance among (VA) and within (VW) the repetition, median, and selective accuracy (SA) for the lesion size $\left(\mathrm{cm}^{2}\right.$ fruit $\left.^{-1}\right)$ on peaches.

\begin{tabular}{lccccc}
\hline SV & DF & MS-C1 & MS-C2 & MS-M1 & MS-M2 \\
\hline FPE & 3 & $1441.95^{*}$ & $1195.92^{*}$ & $565.23^{*}$ & $817.55^{*}$ \\
VA & 16 & $43.75^{\text {ns }}$ & $14.79^{\text {ns }}$ & $36.79^{\text {ns }}$ & $23.28^{\text {ns }}$ \\
VW & 80 & 39.98 & 23.85 & 29.11 & 19.42 \\
Median & - & 17.44 & 16.28 & 17.52 & 14.86 \\
SA & - & 0.985 & 0.994 & 0.967 & 0.986 \\
& & & & & \\
FAE & 6 & $1571.95^{*}$ & $516.00^{*}$ & $825.54^{*}$ & $493.36^{*}$ \\
VA & 28 & $58.23^{*}$ & $11.20^{*}$ & $26.42^{*}$ & $15.70^{*}$ \\
VW & 174 & 10.90 & 7.12 & 7.77 & 5.44 \\
Median & - & 19.03 & 20.27 & 20.03 & 22.16 \\
SA & - & 0.981 & 0.989 & 0.984 & 0.984 \\
\hline
\end{tabular}

${ }^{*}$ significant effect as measure by $\mathrm{F}$ test $(\mathrm{p}<0.05) ;{ }^{\text {ns }}$ non-significant effect.

Table 2. Number of fruits measured $(\mathrm{N})$, minimum value (Min), maximum value (Max), average, standard deviation (SD), coefficient of variance $(\mathrm{CV} \%)$, estimation of asymmetry (ASS), and kurtosis $+3(\mathrm{KT})$, and the result of Lilliefors normality test (LT) related to the lesion size $\left(\mathrm{cm}^{2}\right.$ fruto $\left.{ }^{-1}\right)$ on peaches subjected to different forms of extracts preparations (FPE).

\begin{tabular}{|c|c|c|c|c|c|c|c|c|c|}
\hline $\mathrm{FPE}^{(4)}$ & $\mathrm{N}$ & Min & Max & Average & $\mathrm{SD}$ & $\mathrm{CV}(\%)$ & $\mathrm{ASS}^{(1)}$ & $\mathrm{KT}^{(2)}$ & $\mathrm{LT}^{(3)}$ \\
\hline & \multicolumn{9}{|c|}{ Canola extract - batch 1} \\
\hline Test & 25 & 20.13 & 34.66 & 26.48 & 4.40 & 16.6 & $0.371^{\mathrm{ns}}$ & $1.940^{\mathrm{ns}}$ & $0.235^{*}$ \\
\hline EAq & 25 & 0.50 & 22.50 & 8.98 & 6.66 & 74.2 & $0.390^{\mathrm{ns}}$ & $2.249^{\mathrm{ns}}$ & $0.241^{*}$ \\
\hline EIn & 25 & 11.75 & 29.42 & 20.28 & 5.82 & 28.7 & $0.119^{\text {ns }}$ & $1.805^{\mathrm{ns}}$ & $0.185^{*}$ \\
\hline \multirow[t]{2}{*}{ Ema } & 25 & 2.05 & 28.10 & 14.03 & 8.05 & 57.4 & $0.035^{\text {ns }}$ & $2.012^{\mathrm{ns}}$ & $0.161^{*}$ \\
\hline & \multicolumn{9}{|c|}{ Canola extract - batch 2} \\
\hline Test & 25 & 21.28 & 34.52 & 25.90 & 3.26 & 12.6 & $0.715^{\mathrm{ns}}$ & $3.364^{\mathrm{ns}}$ & $0.208^{*}$ \\
\hline EAq & 25 & 0.34 & 18.97 & 9.43 & 6.25 & 66.2 & $-0.064^{\mathrm{ns}}$ & $1.616^{\mathrm{ns}}$ & $0.229 *$ \\
\hline EIn & 25 & 7.12 & 21.90 & 14.50 & 4.09 & 28.2 & $0.201^{\mathrm{ns}}$ & $2.553^{\mathrm{ns}}$ & $0.172^{\mathrm{ns}}$ \\
\hline \multirow[t]{2}{*}{ Ema } & 25 & 6.64 & 25.45 & 15.30 & 4.79 & 31.3 & $0.037^{\text {ns }}$ & $2.976^{\mathrm{ns}}$ & $0.144^{\mathrm{ns}}$ \\
\hline & \multicolumn{9}{|c|}{ Mustard extract - batch 1} \\
\hline Test & 25 & 12.85 & 31.24 & 22.50 & 4.95 & 22.0 & $-0.136^{\mathrm{ns}}$ & $2.293^{\mathrm{ns}}$ & $0.092^{\mathrm{ns}}$ \\
\hline EAq & 25 & 1.00 & 21.80 & 11.81 & 5.09 & 43.1 & $-0.385^{\mathrm{ns}}$ & $3.589^{\mathrm{ns}}$ & $0.103^{\mathrm{ns}}$ \\
\hline EIn & 25 & 7.45 & 35.30 & 20.13 & 6.21 & 30.9 & $-0.074^{\mathrm{ns}}$ & $3.787^{\mathrm{ns}}$ & $0.119^{\mathrm{ns}}$ \\
\hline \multirow[t]{2}{*}{ Ema } & 25 & 5.17 & 26.39 & 15.63 & 5.71 & 36.5 & $-0.174^{\mathrm{ns}}$ & $2.700^{\mathrm{ns}}$ & $0.139^{\mathrm{ns}}$ \\
\hline & \multicolumn{9}{|c|}{ Mustard extract - batch 2} \\
\hline Test & 25 & 13.39 & 29.65 & 20.05 & 3.87 & 19.3 & $0.170^{\mathrm{ns}}$ & $3.296^{\mathrm{ns}}$ & $0.147^{\mathrm{ns}}$ \\
\hline EAq & 25 & 0.00 & 15.95 & 7.13 & 5.12 & 71.8 & $0.416^{\text {ns }}$ & $2.022^{\mathrm{ns}}$ & $0.247 *$ \\
\hline EIn & 25 & 10.50 & 34.04 & 18.15 & 4.99 & 27.5 & $1.123 *$ & $6.052 *$ & $0.161^{\mathrm{ns}}$ \\
\hline Ema & 25 & 8.70 & 21.54 & 14.10 & 3.77 & 26.7 & $0.226^{\text {ns }}$ & $1.863^{\mathrm{ns}}$ & $0.187^{*}$ \\
\hline
\end{tabular}

The causes for the differences in resizing $\mathrm{J}$ and $\mathrm{K}$ of the two experiments are possibly owing to the effects of treatments applied on the fruits, inducing greater variability in lesions' sizes among the FPE experiment fruits. In experiment FPE, the average of the standard deviation ( $\mathrm{SD}$, Table 2) is 
equal to 5.19 and the coefficient of variance $(\mathrm{CV})$ is equal to $37.1 \%$, which are higher than those obtained in experiment FAE (Table 3), $\mathrm{SD}=3.20$ and $\mathrm{CV}=$ $17.8 \%$. In experiment FAE, with a lower SD (lesions size of the most homogeneous fruits), it is feasible to employ a smaller sampling size, and, consequently (BARBIN, 1998), a greater number of repetitions to obtain even more precision (lower estimate of variance of the estimated median of a treatment).

Table 3. Number of measured fruits (N), minimum value (Min), maximum value (Max), average, standard deviation (SD), variance coefficient $(\mathrm{CV} \%)$, asymmetry estimate (ASS), and kurtosis $+3(\mathrm{KT})$, and result of the Lilliefors normality test (LT) for the lesion size $\left(\mathrm{cm}^{2}\right.$ fruto $\left.{ }^{-1}\right)$ on peaches subjected to different forms of extracts applications (FAE).

\begin{tabular}{|c|c|c|c|c|c|c|c|c|c|}
\hline $\mathrm{FAE}^{(4)}$ & $\mathrm{N}$ & Min & Max & Average & SD & $\mathrm{CV}(\%)$ & $\mathrm{ASS}^{(1)}$ & $\mathrm{KT}^{(2)}$ & $\mathrm{LT}^{(3)}$ \\
\hline & \multicolumn{9}{|c|}{ Canola extract - batch 1} \\
\hline T1 & 25 & 19.50 & 38.20 & 28.90 & 5.51 & 19.1 & $-0.091^{\mathrm{ns}}$ & $1.686^{\mathrm{ns}}$ & $0.108^{\mathrm{ns}}$ \\
\hline $\mathrm{T} 2$ & 25 & 9.00 & 27.30 & 19.42 & 4.97 & 25.6 & $-0.296^{\mathrm{ns}}$ & $2.056^{\mathrm{ns}}$ & $0.093^{\mathrm{ns}}$ \\
\hline $\mathrm{T} 3$ & 25 & 5.60 & 17.90 & 11.76 & 3.30 & 28.1 & $0.046^{\mathrm{ns}}$ & $1.869^{\mathrm{ns}}$ & $0.100^{\mathrm{ns}}$ \\
\hline $\mathrm{T} 4$ & 25 & 3.30 & 17.20 & 9.92 & 3.74 & 37.7 & $0.044^{\mathrm{ns}}$ & $2.330^{\mathrm{ns}}$ & $0.125^{\mathrm{ns}}$ \\
\hline T5 & 25 & 2.00 & 21.70 & 11.76 & 4.97 & 42.3 & $-0.190^{\mathrm{ns}}$ & $2.237^{\mathrm{ns}}$ & $0.127^{\mathrm{ns}}$ \\
\hline T6 & 25 & 22.50 & 34.10 & 26.44 & 2.25 & 8.5 & $1.229^{\mathrm{ns}}$ & $6.072 *$ & $0.164^{\mathrm{ns}}$ \\
\hline \multirow[t]{2}{*}{$\mathrm{T} 7$} & 25 & 11.30 & 32.17 & 25.04 & 4.67 & 18.7 & $-0.844^{\mathrm{ns}}$ & $3.832^{\mathrm{ns}}$ & $0.077^{\mathrm{ns}}$ \\
\hline & \multicolumn{9}{|c|}{ Canola extract- batch 2} \\
\hline $\mathrm{T} 1$ & 25 & 20.00 & 32.90 & 24.13 & 2.65 & 11.0 & $1.322^{\mathrm{ns}}$ & $5.539 *$ & $0.170^{\mathrm{ns}}$ \\
\hline $\mathrm{T} 2$ & 25 & 17.20 & 26.65 & 22.19 & 2.82 & 12.7 & $-0.259^{\mathrm{ns}}$ & $1.771^{\mathrm{ns}}$ & $0.109^{\text {ns }}$ \\
\hline T3 & 25 & 13.20 & 22.60 & 18.45 & 2.71 & 14.7 & $-0.327^{\mathrm{ns}}$ & $2.059^{\mathrm{ns}}$ & $0.077^{\mathrm{ns}}$ \\
\hline T4 & 25 & 4.50 & 19.10 & 11.92 & 3.89 & 32.7 & $-0.177^{\mathrm{ns}}$ & $2.344^{\mathrm{ns}}$ & $0.102^{\mathrm{ns}}$ \\
\hline T5 & 25 & 13.50 & 22.00 & 17.77 & 2.37 & 13.3 & $0.169^{\mathrm{ns}}$ & $1.971^{\mathrm{ns}}$ & $0.123^{\mathrm{ns}}$ \\
\hline T6 & 25 & 21.30 & 27.80 & 24.71 & 2.01 & 8.1 & $-0.108^{\mathrm{ns}}$ & $1.599^{\mathrm{ns}}$ & $0.136^{\mathrm{ns}}$ \\
\hline \multirow[t]{2}{*}{$\mathrm{T} 7$} & 25 & 18.40 & 27.10 & 22.76 & 2.74 & 12.0 & $0.014 \mathrm{~ns}$ & $1.475^{\mathrm{ns}}$ & $0.140^{\mathrm{ns}}$ \\
\hline & \multicolumn{9}{|c|}{ Mustard extract - batch 1} \\
\hline $\mathrm{T} 1$ & 25 & 22.40 & 35.40 & 28.47 & 3.32 & 11.7 & $0.158^{\mathrm{ns}}$ & $2.126^{\mathrm{ns}}$ & $0.087^{\mathrm{ns}}$ \\
\hline $\mathrm{T} 2$ & 25 & 15.40 & 24.30 & 19.15 & 2.32 & 12.1 & $0.235^{\text {ns }}$ & $2.161^{\mathrm{ns}}$ & $0.121^{\mathrm{ns}}$ \\
\hline $\mathrm{T} 3$ & 25 & 5.70 & 25.00 & 15.73 & 4.71 & 30.0 & $-0.374^{\mathrm{ns}}$ & $2.426^{\mathrm{ns}}$ & $0.126^{\mathrm{ns}}$ \\
\hline $\mathrm{T} 4$ & 25 & 5.33 & 23.70 & 12.90 & 3.61 & 28.0 & $0.615^{\mathrm{ns}}$ & $4.417^{\mathrm{ns}}$ & $0.111^{\mathrm{ns}}$ \\
\hline T5 & 25 & 9.70 & 21.10 & 15.95 & 3.21 & 20.1 & $-0.499^{\text {ns }}$ & $2.190^{\mathrm{ns}}$ & $0.122^{\mathrm{ns}}$ \\
\hline T6 & 25 & 22.90 & 31.00 & 26.07 & 2.19 & 8.4 & $0.532^{\text {ns }}$ & $2.234^{\mathrm{ns}}$ & $0.140^{\mathrm{ns}}$ \\
\hline \multirow[t]{2}{*}{$\mathrm{T} 7$} & 25 & 15.60 & 27.50 & 21.93 & 3.07 & $\begin{array}{c}0.7 \\
14.0\end{array}$ & $-0.397^{\mathrm{ns}}$ & $2.640^{\mathrm{ns}}$ & $0.089^{\mathrm{ns}}$ \\
\hline & \multicolumn{9}{|c|}{ Mustard extract- batch 2} \\
\hline $\mathrm{T} 1$ & 25 & 20.20 & 29.20 & 24.40 & 2.09 & 8.6 & $0.242^{\mathrm{ns}}$ & $2.532^{\mathrm{ns}}$ & $0.100^{\mathrm{ns}}$ \\
\hline $\mathrm{T} 2$ & 25 & 17.60 & 31.00 & 21.95 & 2.78 & 12.6 & $0.977^{\mathrm{ns}}$ & $5.389^{*}$ & $0.167^{\mathrm{ns}}$ \\
\hline $\mathrm{T} 3$ & 25 & 18.00 & 29.70 & 22.50 & 2.32 & 10.3 & $0.863^{\text {ns }}$ & $4.724^{\mathrm{ns}}$ & $0.118^{\mathrm{ns}}$ \\
\hline $\mathrm{T} 4$ & 25 & 5.10 & 18.80 & 12.75 & 3.33 & 26.1 & $-0.093^{\mathrm{ns}}$ & $2.386^{\mathrm{ns}}$ & $0.101^{\mathrm{ns}}$ \\
\hline T5 & 25 & 17.20 & 28.20 & 22.72 & 3.01 & 13.3 & $0.222^{\mathrm{ns}}$ & $1.980^{\mathrm{ns}}$ & $0.142^{\mathrm{ns}}$ \\
\hline T6 & 25 & 21.00 & 30.70 & 26.66 & 2.68 & 10.0 & $-0.446^{\mathrm{ns}}$ & $2.254^{\mathrm{ns}}$ & $0.071^{\mathrm{ns}}$ \\
\hline $\mathrm{T} 7$ & 25 & 19.70 & 28.10 & 24.18 & 2.29 & 9.5 & $-0.252^{\mathrm{ns}}$ & $2.004^{\mathrm{ns}}$ & $0.087^{\text {ns }}$ \\
\hline
\end{tabular}

${ }^{(1) * A s y m m e t r y ~ d i f f e r s ~ f r o m ~ z e r o, ~ b y ~ t-t e s t ~}(\mathrm{p}=0.05)$ and ${ }^{\mathrm{ns}}=$ non-significant; ${ }^{(2)} *$ kurtosis differs from three, by $\mathrm{t}$-test $(\mathrm{p}$ $=0.05)$ and ${ }^{\mathrm{ns}}$ non-significant; ${ }^{(3)} \mathrm{ns}$ Normal distribution $(\mathrm{p}>0.05) ;{ }^{(4)} \mathrm{T} 1=$ Witness; T2 $=\mathrm{In} \rightarrow \mathrm{Ap} ; \mathrm{T} 3=\mathrm{Ap} \rightarrow \mathrm{In} ; \mathrm{T} 4=$ $\mathrm{Ap} \rightarrow \mathrm{In} \rightarrow \mathrm{Te} \rightarrow \mathrm{Ap} ; \mathrm{T} 5=\mathrm{Ap} \rightarrow \mathrm{In} \rightarrow \mathrm{Te} ; \mathrm{T} 6=\mathrm{In} \rightarrow \mathrm{Te} ; \mathrm{T} 7=\mathrm{In} \rightarrow \mathrm{Te} \rightarrow \mathrm{Ap}$, where $\mathrm{In}=$ Inoculation, Ap $=$ extract application, $\mathrm{Te}=$ Thermotherapy; $\rightarrow=$ sequence.

Tables 2 and 3 show the minimum and maximum values, average, and the indicators related to the distribution of probability of the lesions sizes. For the FAE experiment (Table 3), data from all treatments, extracts, and batches were analyzed by means of the normal distribution, since the hypotheses of normality were not declined in any of the cases. In the FPE experiment, the results did not demonstrate normal distribution for half of the cases, and in these same cases, the hypotheses related to asymmetry and kurtosis were not rejected, indicating possible proximity of normality. Therefore, it is feasible to use the $t$-distribution for estimating the sampling size based on the Student's $t$-distribution in all cases.

The sample size $(\eta$, number of fruits per treatment) for estimating the median of the lesion size, with semi-amplitude of the confidence interval (SACI) equal to $2 \%$ of the average estimate ( $\mathrm{SACI}$ $=2 \%), \mathrm{SACI}=4 \%, \mathrm{SACI}=6 \%$, SACI $=8 \%$ and $\mathrm{SACI}=10 \%)$ are presented in Tables 4 and 5 . The estimate of $\eta$ must be size-measured adequately between the number of repetitions $(\mathrm{J})$ and the number of fruits per repetition $(\mathrm{K})$, so that $\eta=\mathrm{JK}$. The sample size is reduced with increases in SACI values. For some combinations of treatments, extracts, and batches, the sample size is either extremely high or smaller than the 25 fruits employed in the experiments.

The values of SACI $(1-p=0.95)$ in Tables 4 and 5 reflect the influence of the treatments in the precision of the estimates of the treatment averages. 
Variations in sample size related to the treatments applied were also cited in studies of different features of peach fruits (TOEBE et al., 2011 and 2012). These studies also reported a large amplitude of variance of $\eta$ in function of the "estimation error" and treatments applied to fruits.

Table 4. Sample size (number of fruits) for estimation of the area median $\left(\mathrm{cm}^{2} \mathrm{fruto}^{-1}\right)$ of the lesion on peaches, evaluated under different forms of extract preparation (FPE) for an estimation error equal to $\mathrm{SACI}=2,4,6,8$ and $10 \%$ of the average estimate and semi-amplitude of the confidence interval (SACI\%), based on the number of fruits measured $(n=25)$.

\begin{tabular}{|c|c|c|c|c|c|c|c|}
\hline $\mathrm{FPE}^{(1)}$ & $\mathrm{N}$ & $\mathrm{SACI}=2 \%$ & $\mathrm{SACI}=4 \%$ & $\mathrm{SACI}=6 \%$ & $\mathrm{SACI}=8 \%$ & $\mathrm{SACI}=10 \%$ & $\mathrm{SACI} \%$ \\
\hline & \multicolumn{7}{|c|}{ Canola extract - batch 1} \\
\hline Test & 25 & 395.3 & 98.8 & 43.9 & 24.7 & 15.8 & 8.0 \\
\hline EAq & 25 & 226.8 & 56.7 & 25.2 & 14.2 & 9.1 & 6.0 \\
\hline EIn & 25 & 691.6 & 172.9 & 76.8 & 43.2 & 27.7 & 10.5 \\
\hline \multirow[t]{2}{*}{ Ema } & 25 & 531.4 & 132.8 & 59.0 & 33.2 & 21.3 & 9.2 \\
\hline & \multicolumn{7}{|c|}{ Canola extract - batch 2} \\
\hline Test & 25 & 7861.8 & 1965.4 & 873.5 & 491.4 & 314.5 & 35.5 \\
\hline EAq & 25 & 6265.3 & 1566.3 & 696.1 & 391.6 & 250.6 & 31.7 \\
\hline EIn & 25 & 2656.4 & 664.1 & 295.2 & 166.0 & 106.3 & 20.6 \\
\hline \multirow[t]{2}{*}{ Ema } & 25 & 7367.9 & 1842.0 & 818.7 & 460.5 & 294.7 & 34.3 \\
\hline & \multicolumn{7}{|c|}{ Mustard extract - batch 1} \\
\hline Test & 25 & 1177.0 & 294.2 & 130.8 & 73.6 & 47.1 & 13.7 \\
\hline EAq & 25 & 1138.2 & 284.5 & 126.5 & 71.1 & 45.5 & 13.5 \\
\hline EIn & 25 & 1360.9 & 340.2 & 151.2 & 85.1 & 54.4 & 14.8 \\
\hline \multirow[t]{2}{*}{ EMa } & 25 & 1078.5 & 269.6 & 119.8 & 67.4 & 43.1 & 13.1 \\
\hline & \multicolumn{7}{|c|}{ Mustard extract - batch 2} \\
\hline Test & 25 & 4704.8 & 1176.2 & 522.8 & 294.0 & 188.2 & 27.4 \\
\hline EAq & 25 & 1402.3 & 350.6 & 155.8 & 87.6 & 56.1 & 15.0 \\
\hline EIn & 25 & 1904.3 & 476.1 & 211.6 & 119.0 & 76.2 & 17.5 \\
\hline EMa & 25 & 1021.2 & 255.3 & 113.5 & 63.8 & 40.8 & 12.8 \\
\hline
\end{tabular}

(1) Test = witness, EAq = aqueous extract, EIn = extract by infusion, EMa = extract by maceration.

Table 5. Sample size (number of fruits) for estimation of the area median $\left(\mathrm{cm}^{2}\right.$ fruto $\left.{ }^{-1}\right)$ of the lesions on peaches evaluated under different forms of extract application (FAE) for estimation errors equal to $\mathrm{SACI}=2,4,6,8$, and $10 \%$ of the average estimation and semi-amplitude of the confidence interval (SACI\%), based on the fruits measured $(\mathrm{n}=25)$.

\begin{tabular}{|c|c|c|c|c|c|c|c|}
\hline Trat $^{(1)}$ & $\mathrm{N}$ & $\mathrm{SACI}=2 \%$ & $\mathrm{SACI}=4 \%$ & $\mathrm{SACI}=6 \%$ & $\mathrm{SACI}=8 \%$ & $\mathrm{SACI}=10 \%$ & $\mathrm{SACI} \%$ \\
\hline & \multicolumn{7}{|c|}{ Canola extract- batch 1} \\
\hline $\mathrm{T} 1$ & 25 & 519.4 & 129.9 & 57.7 & 32.5 & 20.8 & 9.1 \\
\hline $\mathrm{T} 2$ & 25 & 172.3 & 43.1 & 19.1 & 10.8 & 6.9 & 5.3 \\
\hline $\mathrm{T} 3$ & 25 & 194.1 & 48.5 & 21.6 & 12.1 & 7.8 & 5.6 \\
\hline $\mathrm{T} 4$ & 25 & 105.2 & 26.3 & 11.7 & 6.6 & 4.2 & 4.1 \\
\hline T5 & 25 & 936.4 & 234.1 & 104.0 & 58.5 & 37.5 & 12.2 \\
\hline T6 & 25 & 230.3 & 57.6 & 25.6 & 14.4 & 9.2 & 6.1 \\
\hline \multirow[t]{2}{*}{$\mathrm{T} 7$} & 25 & 208.8 & 52.2 & 23.2 & 13.1 & 8.4 & 5.8 \\
\hline & \multicolumn{7}{|c|}{ Canola Extract- batch 2} \\
\hline $\mathrm{T} 1$ & 25 & 228.7 & 57.2 & 25.4 & 14.3 & 9.1 & 6.0 \\
\hline $\mathrm{T} 2$ & 25 & 1127.4 & 281.8 & 125.3 & 70.5 & 45.1 & 13.4 \\
\hline $\mathrm{T} 3$ & 25 & 308.1 & 77.0 & 34.2 & 19.3 & 12.3 & 7.0 \\
\hline $\mathrm{T} 4$ & 25 & 1283.3 & 320.8 & 142.6 & 80.2 & 51.3 & 14.3 \\
\hline T5 & 25 & 151.9 & 38.0 & 16.9 & 9.5 & 6.1 & 4.9 \\
\hline T6 & 25 & 2029.8 & 507.4 & 225.5 & 126.9 & 81.2 & 18.0 \\
\hline $\mathrm{T} 7$ & 25 & 1525.6 & 381.4 & 169.5 & 95.3 & 61.0 & 15.6 \\
\hline & \multicolumn{7}{|c|}{ Mustard extract - batch 1} \\
\hline $\mathrm{T} 1$ & 25 & 1120.5 & 280.1 & 124.5 & 70.0 & 44.8 & 13.4 \\
\hline $\mathrm{T} 2$ & 25 & 975.3 & 243.8 & 108.4 & 61.0 & 39.0 & 12.5 \\
\hline $\mathrm{T} 3$ & 25 & 2554.7 & 638.7 & 283.9 & 159.7 & 102.2 & 20.2 \\
\hline T4 & 25 & 253.7 & 63.4 & 28.2 & 15.9 & 10.1 & 6.4 \\
\hline $\mathrm{T} 5$ & 25 & 577.7 & 144.4 & 64.2 & 36.1 & 23.1 & 9.6 \\
\hline T6 & 25 & 251.6 & 62.9 & 28.0 & 15.7 & 10.1 & 6.3 \\
\hline $\mathrm{T} 7$ & 25 & 103.1 & 25.8 & 11.5 & 6.4 & 4.1 & 4.1 \\
\hline
\end{tabular}

(1) $\mathrm{T} 1=$ Witness; T2 = In $\rightarrow \mathrm{Ap} ; \mathrm{T} 3=\mathrm{Ap} \rightarrow \mathrm{In} ; \mathrm{T} 4=\mathrm{Ap} \rightarrow \mathrm{In} \rightarrow \mathrm{Te} \rightarrow \mathrm{Ap} ; \mathrm{T} 5=\mathrm{Ap} \rightarrow \mathrm{In} \rightarrow \mathrm{Te} ; \mathrm{T} 6=\mathrm{In} \rightarrow \mathrm{Te} ; \mathrm{T} 7=\mathrm{In} \rightarrow \mathrm{Te} \rightarrow \mathrm{Ap}$, where $\mathrm{In}=$ Inoculation, $\mathrm{Ap}=$ Extract application, $\mathrm{Te}=$ Thermotherapy; $\rightarrow=$ sequence. 
Table 5. continuation.

\begin{tabular}{lccccccc}
\hline Trat $^{(1)}$ & N & SACI $=2 \%$ & SACI $=4 \%$ & SACI $=6 \%$ & SACI $=8 \%$ & SACI $=10 \%$ & SACI $\%$ \\
\hline & & \multicolumn{5}{c}{ Mustard extract- batch 2} \\
T1 & 25 & 94.6 & 23.7 & 10.5 & 5.9 & 3.8 & 3.9 \\
T2 & 25 & 101.2 & 25.3 & 11.2 & 6.3 & 4.0 & 4.0 \\
T3 & 25 & 144.1 & 36.0 & 16.0 & 9.0 & 5.8 & 4.8 \\
T4 & 25 & 497.1 & 124.3 & 55.2 & 31.1 & 19.9 & 8.9 \\
T5 & 25 & 206.6 & 51.6 & 23.0 & 12.9 & 8.3 & 5.7 \\
T6 & 25 & 279.6 & 69.9 & 31.1 & 17.5 & 11.2 & 6.7 \\
T7 & 25 & 128.1 & 32.0 & 14.2 & 8.0 & 5.1 & 4.5 \\
\hline
\end{tabular}

(1) $\mathrm{T} 1=$ Witness; $\mathrm{T} 2=\mathrm{In} \rightarrow \mathrm{Ap} ; \mathrm{T} 3=\mathrm{Ap} \rightarrow \mathrm{In} ; \mathrm{T} 4=\mathrm{Ap} \rightarrow \mathrm{In} \rightarrow \mathrm{Te} \rightarrow \mathrm{Ap} ; \mathrm{T} 5=\mathrm{Ap} \rightarrow \mathrm{In} \rightarrow \mathrm{Te} ; \mathrm{T} 6=\mathrm{In} \rightarrow \mathrm{Te} ; \mathrm{T} 7=$ $\mathrm{In} \rightarrow \mathrm{Te} \rightarrow \mathrm{Ap}$, where In $=$ Inoculation, Ap $=$ Extract application, $\mathrm{Te}=$ Thermotherapy; $\rightarrow=$ sequence.

By fixing the "estimation error" at $10 \%$ of the median (Table 4, SACI $=10 \%$ ) in experiment FPE, $\eta$ varied from nine until 315 , with the largest values for the canola extract in batch 2 (average of 241 fruits) and the smallest in canola extract in batch 2 (average of 19 fruits). The median of $\eta$ related the mustard extract was 69 fruits (48 in batch 1 , and 90 in batch 2). It is possible that the fruits harvested in different batches had different degrees of maturation (or another feature), thus influencing the variability or sensitivity to the applied treatments.

By fixing the "estimation error" at $10 \%$ of the median (Table 5, SACI $=10 \%$ ), in experiment FAE, $\eta$ ranged from 4-102, with the largest values for canola extract in batch 2 (average of 38 fruits), and the lowest for mustard extract in batch 2 (average of 8 fruits). The median of $\eta$ related to the mustard extract was 21 fruits (33 in batch 1, and 08 in batch $2)$. Therefore, the averages of $\eta$ for the extracts and application batches do not correlate with each other, perhaps due to the significance of variance among repetitions in the FAE experiment.

In comparing the $\eta$ value among the treatments, in the FPE experiment $(\mathrm{SACI}=10 \%)$, the largest values of $\eta$ were obtained in the control treatment (average of 141 fruits). In the FAE experiment, the average of the control treatment was 20 fruits, which was similar to the remaining treatments. In addition, less than 25 fruits per treatment were used in most of the treatments.

It is therefore the responsibility of the researcher to determine the level of precision for estimating the experimental medians. Accordingly, higher precision requires a larger sample size. However, it is also important to consider the variability of human resources, research material, and financial resources. Tables 4 and 5 show the required information for determining the level of precision needed. Samples sizes are feasible for a precision of $\mathrm{SACI}=10 \%$. In this case, for the FAE experiment, 24 fruits could be distributed into 12 repetitions of two fruits.

Selective accuracy (SA, Table 1) is a precision measurement recommended as suitable for evaluating the precision of cultivar trials of corn (CARGNELUTTI FILHO; STORCK, 2009), soybean and beans (CARGNELUTTI FILHO et al., 2009b), and wheat (BENIN et al., 2013). The SA determined in this study for both FAE and FPE experiments is classified as greatly accurate (SA > 0.90 ), according to a scale proposed by Resende and Duarte (2007). This precision indicates that the number of fruits per treatment used in this study was sufficient. However, this number of fruits $(\mathrm{JK}=25)$ could be re-sized in relation to the five repetitions used, thus reducing the number of repetitions in the FPE experiment and increasing the number of repetitions in the FAE experiment.

\section{CONCLUSIONS}

Approximately 99 fruits are sufficient for estimating the average with an error margin of $10 \%$ as it relates to legion size of brown rot on peaches in experiments using various forms of extract preparations. In addition, 23 fruits are suitable in experiments using various forms of extract applications.

For the same estimation error, the sampling size (number of fruits) is contingent on the extracts (canola and mustard), fruit batches, and extraction and application forms of the extracts on the fruits.

\section{ACKNOWLEDGEMENT}

Special thanks to the National Council for Scientific and Technological Development (CNPq), and to Corporation for the Improvement of Higher Education Personnel (CAPES), for the funding to conduct this research.

\section{REFERENCES}

BARBETTA, P. A.; REIS, M. M.; BORNIA, A. C. Estatística para cursos de engenharia e 
informática. 2. ed. São Paulo, SP: Atlas, 2004. 410 p.

BARBIN, D. Componentes de variância - teoria e aplicações. 2. ed. Piracicaba, SP: FEALQ, 1998. 120 p.

BELASQUE JÚNIOR, J. et al. Tamanho da amostra para quantificação do diâmetro de lesões de cancro cítrico. Tropical Plant Pathology, Viçosa, v. 33, n. 4, p. 317-322, 2008.

BENIN, G. et al. Precisão experimental de ensaios de trigo em regiões homogêneas de adaptação. Pesquisa Agropecuária Brasileira, Brasília, v. 48, n. 4, p. 365-372, 2013.

CARGNELUTTI FILHO, A.; STORCK, L. Medidas do grau de precisão experimental em ensaios de competição de cultivares de milho. Pesquisa Agropecuária Brasileira, Brasília, v. 44, n. 2, p. 111-117, 2009.

CARGNELUTTI FILHO, A. et al. Tamanho de amostra de caracteres de genótipos de soja. Ciência Rural, Santa Maria, v. 39, n. 4, p. 983-991, 2009.

CARGNELUTTI FILHO, A. et al. Tamanho de amostra de caracteres em híbridos de mamoneira. Ciência Rural, Santa Maria, v. 40, n. 2, p. 250-257, 2010a.

CARGNELUTTI FILHO, A. et al. Tamanho de amostra e relações lineares de caracteres morfológicos e produtivos de crambe. Ciência Rural, Santa Maria, v. 40, n. 11, p. 2262-2267, $2010 b$.

CASALS, C. et al. Control of Monilinia spp. On stone fruit by curing treatments. Part I. The effect of temperature, exposure time and relative humidity on curing efficacy. Postharvest Biology and Technology, Amsterdam, v. 56, n. 1, p. 19-25, 2010.

CATAPATTI, T. R. et al. Tamanho de amostra e número de repetições para avaliação de caracteres agronômicos em milho-pipoca. Ciência e Agrotecnologia, Lavras, v. 32, n. 3, p. 855-862, 2008.

CHEN, J.; ZHANG, S.; YANG, X. Control of brown rot on nectarines by tea polyphenol combined with tea saponin. Crop Protection, Amsterdam, v. 45, n. 2, p. 29-35, 2013.

FAO. Pêssego e nectarinas: produção, área e rendimento. Disponível em: <http:// www.faostat.fao.org/sit>. Acesso em: Mar. 2014.

FACHINELLO, J. C. et al. Situação e perspectivas da fruticultura de clima temperado no Brasil. Revista Brasileira de Fruticultura, Jaboticabal, v. 33, n 1, p. 109-120, 2011.

FERNANDES, E. N.; SILVA, P. S. L. Tamanho da amostra e método de amostragem para caracteres da espiga do milho. Ciência e Agrotecnologia, Lavras, v. 20 , n. 2, p. 252-256, 1996

HAESBAERT, F. M. et al. Tamanho de amostra para experimentos com feijão-de-vagem em diferentes ambientes. Ciência Rural, Santa Maria, v. 41, n. 1, p. 38-44, 2011.

JANISIEWICZA, W. J. et al. Culturable bacteria from plum fruit surfaces and their potential for controlling brown rot after harvest. Postharvest Biology and Technology, Amsterdam, v. 76, n. 1, p. 145-151, 2013.

KARABULUT, O. A. et al. Control of brown rot and blue mold of peach and nectarine by short hot water brushing and yeast antagonists. Postharvest Biology and Technology, Amsterdam, v. 24, n. 2, p. 103-111, 2002.

LEITE, M. S. O. et al. Sample size for full-sib family evaluation in sugarcane. Pesquisa Agropecuária Brasileira, Brasília, v. 44, n. 12, p. 1562-1574, 2009.

LIU, J. et al. Effect of heat treatment on inhibition of Monilinia fructicola and induction of disease resistance in peach fruit. Postharvest Biology and Technology, Amsterdam, v. 65, n. 1, p. 61-68, 2012.

LÚCIO, A. D. et al. Distribuição espacial e tamanho de amostra para o ácaro do bronzeado da erva-mate. Revista Árvore, Viçosa, v. 33, n. 1, p. 145-150, 2009.

MARI, M. et al. Control of brown rot on stonefruit by synthetic and glucosinolate-derived isothiocyanates. Postharvest Biology and Technology, Amsterdam, v. 47, n. 2, p. 61-67, 2008.

RESENDE, M. D. V.; DUARTE, J. B. Precisão e controle de qualidade em experimentos de avaliação de cultivares. Pesquisa Agropecuária Tropical, Goiânia, v. 37, n. 3, p. 182-194, 2007.

SAEG - Sistema para análises estatísticas. Versão 9.1: Viçosa: UFV, Fundação Arthur Bernardes, 2007.

SILVA， J.; SILVA， P. S. L.; NUNES， R. P Amostragem e tamanho da amostra na estimação de caracteres da espiga do milho. Pesquisa Agropecuária Brasileira, Brasília, v. 33, n. 12, p. 1983-1988, 1998. 
SISQUELLA, M. et al. Immersion of fruit in water to improve radio frequency treatment to control brown rot in stone fruit. Postharvest Biology and Technology, Amsterdam, v. 80, n. 1, p. 31-36, 2013a.

SISQUELLA, M. et al. Combination of peracetic acid and hot water treatment to control postharvest brown rot on peaches and nectarines. Postharvest Biology and Technology, Amsterdam, v. 83, n. 1, p. $1-8,2013 b$.

STORCK, L. et al. Sample size for single, double and triple hybrid corn ear traits. Scientia Agrícola, Piracicaba, v. 64, n. 1, p. 30-35, 2007.

TOEBE, M. et al. Dimensionamento amostral para avaliar firmeza de polpa e cor da epiderme em pêssego e maçã. Revista Ciência Agronômica, Fortaleza, v. 42, n. 4, p. 1026-1035, 2011.

TOEBE, M. et al. Tamanho de amostra para a estimação da média de caracteres de pêssego na colheita e após o armazenamento refrigerado. Ciência Rural, Santa Maria, v. 42, n. 2, p. 209-212, 2012.

THOMIDIS, T.; EXADAKTYLOU, E. Effect of boron on the development of brown rot (Monilinia laxa) on peaches. Crop Protection, Amsterdam, v. 29, n. 6, p. 572-576, 2010.

YANG, L. et al. Difference between chitosan and oligochitosan in growth of Monilinia fructicola and control of brown rot in peach fruit. Food Science and Technology, Atlanta, v. 46, n. 1, p. 254-259, 2012.

ZHOU, T; SCHNEIDER, K.E; LI, X. Development of biocontrol agents from food microbial isolates for controlling post-harvest peach brown rot caused by Monilinia fructicola. International Journal of Food Microbiology, Atlanta, v. 126, n. 2, p. 180-185, 2008. 